Pleione 14(2): 217 - 225. 2020.

(C) East Himalayan Society for Spermatophyte Taxonomy

doi:10.26679/Pleione.14.2.2020.217-225

\title{
Seed morphometry of four species of Dactylorhiza Neck. ex Nevski (Orchidaceae) from Kashmir Himalaya, India
}

\author{
Gowhar A Shapoo $^{1,3}$, Zahoor A Kaloo ${ }^{1}$ and Aijaz Hassan Ganie ${ }^{2}$ \\ ${ }^{1}$ Plant Tissue Culture Research Laboratory, Department of Botany, University of Kashmir, Hazratbal, \\ Srinagar- 190 006, J \& K, India \\ ${ }^{2}$ Department of Botany, University of Kashmir, Kargil Campus, 194 103, Ladakh, India \\ ${ }^{3}$ Corresponding author: gashapoo@gmail.com
}

[Received 12.09.2020; Revised 26.12.2020; Accepted 27.12.2020; Published 31.12.2020]

\begin{abstract}
Seed morphometrical study has been carried out for 4 species of Dactylorhiza Neck. ex Nevski (Orchidaceae) viz. D. hatagirea (D.Don) Soo, D. kafiriana Renz, D. umbrosa (Kar. \& Kir.) Nevski and D. viridis (L.) R.M. Bateman, Pridgeon \& M. W. Chase from Kashmir Himalaya. It has been observed that the seeds are spathulate with ovoid and rectangular testa cells in $D$. hatagirea and $D$. viridis where as in D. Kafriana the seeds are crescent with rectangular testa cells and in D. umbrosa they are elliptic with pentagonal testa cells. All the results of investigation are presented in a table and discussed in detail with the help of photographs.
\end{abstract}

Key words: Dactylorhiza, Seed morphology, Testa-cells, Kashmir Himalaya

\section{INTRODUCTION}

The macro and micro characters of seeds studied under light and scanning electron microscopes are predominant nowadays to delimit different species (Kaya et al. 2011). Orchid seeds are the smallest in the plant kingdom. They are dust like, non-endospermic and comprise an undifferentiated embryo suspended within a membranous and often transparent, but at times pigmented seed coat (Verma et al. 2013). A single fruit of Cycnoches ventricosum var. chlorochilon encloses about 4 million seeds. Because of their small size they are extremely light-weighted and disperse through air. Maximum seed weight, $14-17 \mu \mathrm{g}$, has been reported in Galeola sp. whereas the lowest, $0.3-0.4 \mu \mathrm{g}$ is recorded in Anguloa spp. (Arditti \& Ghani 2000). The seed characteristics are more conserved in orchids than vegetative and floral characters (Chase $\&$ Pippen 1988), and therefore they are very important for taxonomic, phylogenetic, and phytogeographic studies in orchids (Gamarra et al. 2008; Chemisquy et al. 2009). The seed morphology can be utilized to delimit different species within a genus (Augustine et al. 2001; Swamy et al. 2004; Akin et al. 2010; Gammara et al. 2010). Barthlott and Ziegler (1981) reported 20 different types of seeds in orchids based on various morphological characters of seeds. Vij et al. (1992) recognized taxonomic significance of seed characters in 53 orchid species. The morphological variation in shape, size, colour, nature of seed coat, texture of seed coat, the number of testa cells and their size and number greatly vary among different orchid species (Arditi et al. 1980; Augustine et al. 2001). Verma et al. (2012) conducted a study on seed morphometry of seven threatened Himalayan orchids belonging to three different subfamilies, and exhibiting terrestrial (Arundina graminifolia, Cypripedium cordigerum, Habenaria marginata, Herminium monorchis), mycoheterotrophic (Gastrodia falconer) or epiphytic (Aerides multiflora, Pholidota articulata) life modes. It was found that seeds were fusiform, filiform or ovoid in shape and their size showed direct correlation with plant habit. Seeds were smaller in epiphytes as compared to terrestrial or mycoheterotrophic orchid species. Seeds were truncated except in Arundina graminifolia. Scanning Electron Microscopy (SEM) studies revealed that the 
testa cells were longitudinally oriented, arranged either straight or in a spiral, and their periclinal walls were comparatively irregularly placed in epiphytic species. Furthermore Verma et al. (2014) examined physical characteristics of seeds of 32 threatened Western Himalayan orchids belonging to 23 genera of 3 subfamilies using light and scanning electron microscopy. It was observed that these species showed remarkable variations in seed shape (fusiform, spathulate, ovoid, filiform) irrespective of their taxonomic position. The study further reported that epiphytes produced small-sized seeds compared to their terrestrial, lithophytic, or mycoheterotrophic counterparts. Seeds were truncated in 27 species, and were mostly elongated in other orchid species. Swamy et al. (2014) conducted SEM studies on seed morphology of 10 species of epiphytic orchids from Western Ghats of Karnataka. All the investigated taxa are different in their seed surface characters including size, shape, visibility of embryo, testa cells and structure, curvature and ridges. Seed colour ranged from pale yellow to yellow-brown and white. Variations in seed and embryo volume and percentage of air space could exist among the different taxa of orchids. Akbulut and Senel (2016) examined the seeds of 7 Dactylorbiza taxa including 2 endemics from Turkey (D. nieschalkiorum D. osmanica var. osmanica, D. euxina var. euxina, D. iberica, D. romana subsp. romana, D. saccifera, D. urvilleana) in terms of morphological, micromorphological and morphometric properties. They analyzed the seeds using standard procedures of both light and scanning electron microscopy. The seeds collected from different localities were examined in terms of 22 characters, such as seed shape and size, length/width ratio, embryo volume, seed/embryo volume, percent airspace, position of the embryo and seed surface features were analyzed. Furthermore, the morphometric measurements showed that some diagnostic characters could be important for these taxa. As a result of the study, the dendograms were formed based on the numerical analysis and important differences were determined in terms of examined characters among taxa.

Though several reports on orchid seed morphometric studies by using light microscopy and scanning electron microscopy (SEM) techniques are reported from various parts of India, so far no report is published from Jammu and Kashmir Himalayas. Therefore, to fill the gap, for the first time, the present study has been undertaken to analyze seed morphometry of four imperative Dactylorbiza (Orchidaceae) species growing in Kashmir Himalaya-India which may prove useful in species delimitation and taxonomic studies.

\section{MATERIALS AND METHODS}

\section{Study area}

Kashmir Himalaya is situated in northern fringe of the Indian sub-continent between $33^{\circ} 22^{\prime}$ and $34^{\circ} 50^{\prime} \mathrm{N}$ latitudes and $73^{\circ} 55^{\prime}$ and $73^{\circ} 33^{\prime} \mathrm{E}$ longitudes covering an area of about 2, 22.797 sq Km. Extensive field surveys between the months of April to October $(2010-2016)$ covering an altitudinal range of $2100-4300 \mathrm{~m}$ amsl were undertaken in South, Central, North and Western areas of Kashmir. Voucher specimens for each species were collected, processed into mounted herbarium-sheets and deposited in Kashmir University Herbarium (KASH) of the Department of Botany, University of Kashmir, with Voucher Specimen Numbers from 1891 - 1894 (Ref. No. F/GS Herbarium-Specimen vouchers, KU/2016) for the four species of Dactylorbiza.

\section{Collection of plant material and microscopic studies}

The mature seeds of the species under study have been collected from natural populations (Table 1). The geo-coordinates of the selected sites were recorded by using GPS (Model: GPS map76CSx). The morphological characters of seeds were analyzed and photographed with the help of Trinocular Stereo-Zoom Microscope (Model: Carl Zeiss Discovery V8). For SEM studies, double sized conducive tap was fixed with stub, mature seeds were loaded on the stub 
and then sputter coated with gold and finally observed under Scanning Electron Microscope (Model: Hitich-S-3000H). Seed dimensions were measured under light microscope with micrometer.

Table 1. Collection sites and fruiting period of selected species of Dactylorbiza Neck. ex Nevski of Kashmir Himalaya

\begin{tabular}{|c|c|c|c|}
\hline S. No. & Species & $\begin{array}{l}\text { Collection site (Geo- } \\
\text { coordinates), altitude }\end{array}$ & $\begin{array}{l}\text { Fruiting period } \\
\text { (months) }\end{array}$ \\
\hline 1 & D. hatageria & $\begin{array}{l}\text { Daksum - Anantnag } \\
34^{\circ} 22.321^{\prime} \mathrm{N} \& 74^{\circ} 03.321^{\prime} \mathrm{E} \\
3549 \mathrm{~m} \text { amsl }\end{array}$ & August - September \\
\hline 2 & D. kafiriana & $\begin{array}{l}\text { Tulail - Bandipora } \\
34^{\circ} 31.334^{\prime} \mathrm{N} \& 75^{\circ} 10.757^{\prime} \mathrm{E} \\
3212 \mathrm{~m} \text { amsl }\end{array}$ & July - August \\
\hline 3 & D. umbrosa & $\begin{array}{l}\text { Vishansar - Ganderbal } \\
34^{\circ} 24.109^{\prime} \mathrm{N} \& 75^{\circ} 08.122^{\prime} \mathrm{E} \\
3645 \mathrm{~m} \text { amsl }\end{array}$ & August-September \\
\hline 4 & D. viridis & $\begin{array}{l}\text { Vishansar - Ganderbal } \\
34^{\circ} 24.210^{\prime} \mathrm{N} \& 75^{\circ} 08.101^{\prime} \mathrm{E} \\
3704 \mathrm{~m} \text { amsl }\end{array}$ & August - September \\
\hline
\end{tabular}

\section{RESULTS AND DISCUSSION}

The present investigation revealed that the selected orchid species exhibit diversity in the seed shape and size, and also shape and size of testa cells (Table 2 and Plates I - IV). It has been observed that the seeds are spathulate with ovoid and rectangular testa cells in $D$. hatagirea and $D$. viridis where as in D. kafriana the seeds are crescent with rectangular testa cells and in $D$. umbrosa they are elliptic with pentagonal testa cells. The seeds are longer in D. kafiriana followed by $D$. umbrosa and shorter in $D$. viridis followed by $D$. hatagirea. The seed width is broader in $D$. umbrosa followed by $D$. viridis and narrower in D. kafiriana. Longer testa cells are seen in $D$. kafiriana and shorter in D. umbrosa. Similarly testa cells are observed wider in D. hatagirea and narrower in D. umbrosa. The seed coat is transparent-light brown and embryo is dark brown in $D$. hatagirea. In case of $D$. kafiriana the seed coat is transparent and embryo is light brown. In $D$. viridis the seed coat is transparent-light brown and embryo is dark. In D. umbrosa, the seed coat is transparent and embryo is brown in colour. Different morphological characters observed in different species are summarized in Table 2.

The different seed shapes like fusiform, spathulate and elliptic are characteristic feature of orchids (Arditi et al. 1979; Rasmussen 1995; Verma 2014), of which fusiform shape is considered as primitive (Arditi et al. 1979; Verma et al. 2014) and all other shapes are evolved (Verma et al. 2014). With this concept, the species under present study with spathulate, crescent and elliptic shape seeds may be considered as advanced. Further, as per the statement that the longer seeds are considered as primitive over the shorter ones (Vij et al. 1992; Verma et al. 2014), among the present studied species, D. kafiriana may be considered as the most primitive species than the rest three.

From the literature, it is noted that the variation in shape and size of testa cells is also one of the characteristic features of orchid seeds (Vij et al. 1992; Swamy et al. 2004 Verma et al. 

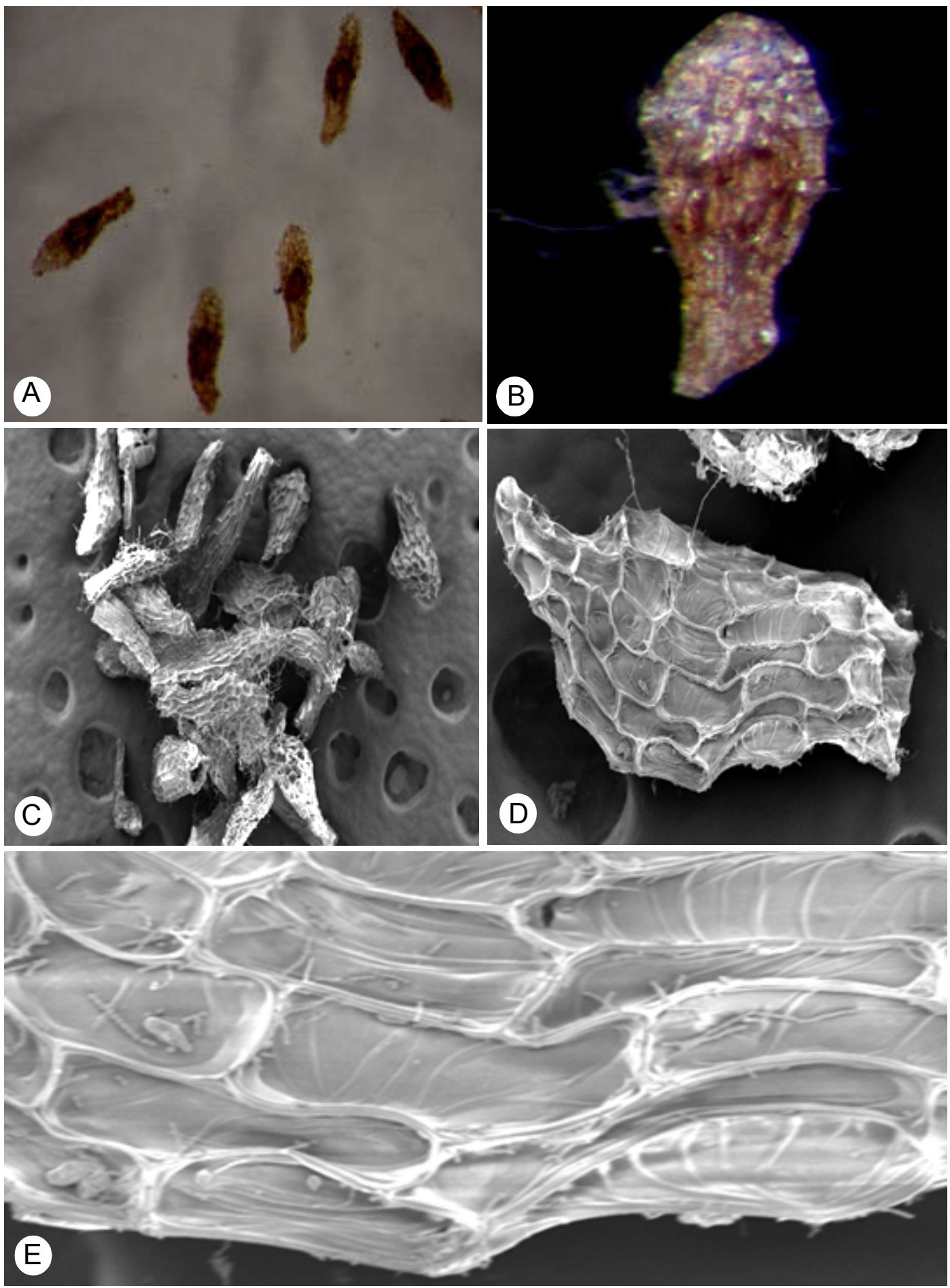

PLATE I. Seed morphometry of Dactylorhiza hatagirea : A \& B. Seeds and single seed in closer view under Stereo-zoom microscope; C - E. Seed shape, coat and testa cells under Scanning Electron Microscope 

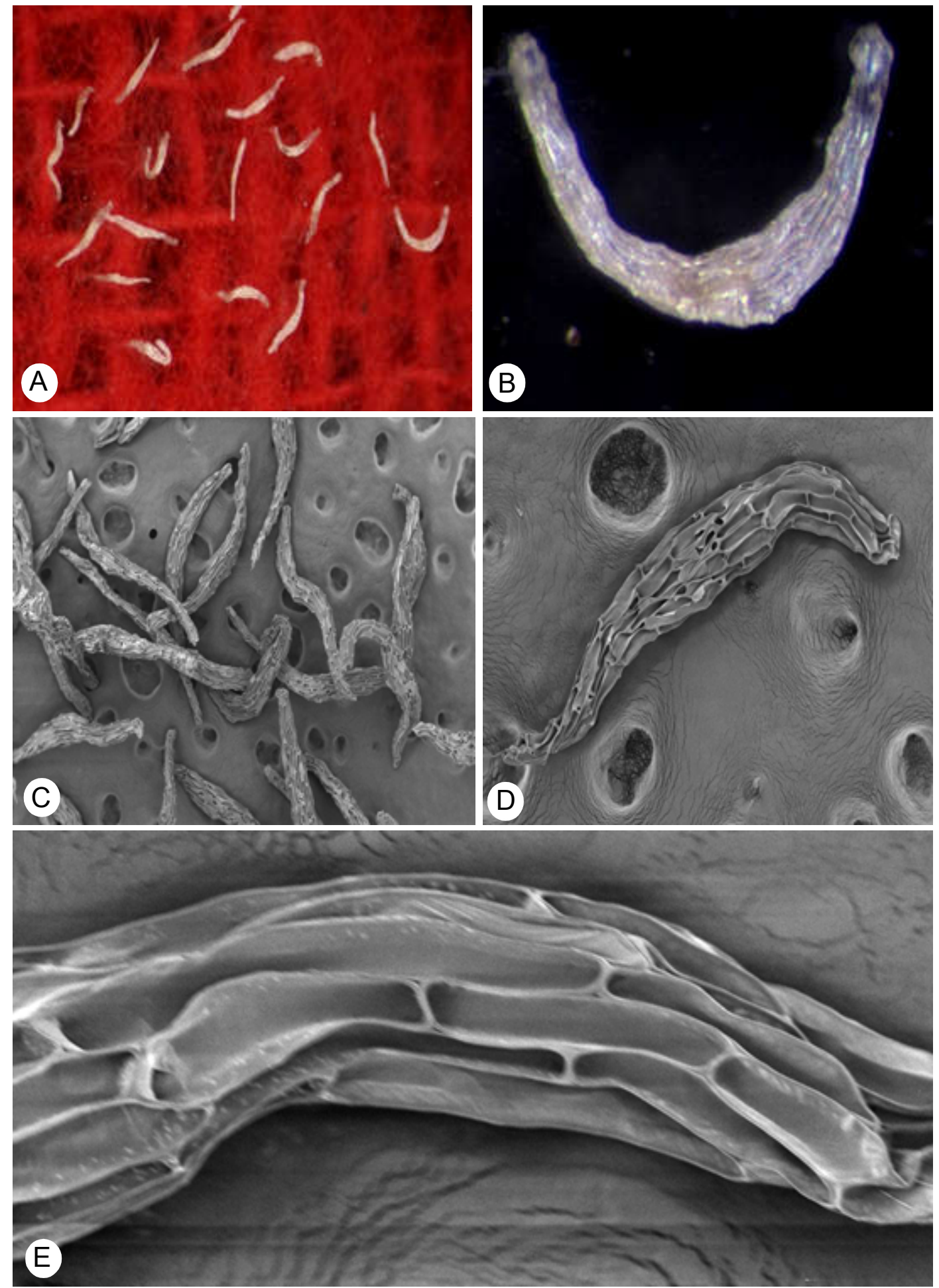

PLATE II. Seed morphometry of Dactylorhiza kafiriana : A \& B. Seeds and single seed in closer view under Stereo-zoom microscope; C - E. Seed shape, coat and testa cells under Scanning Electron Microscope 
222 Seed morphometry of Dactylorhiza spp.
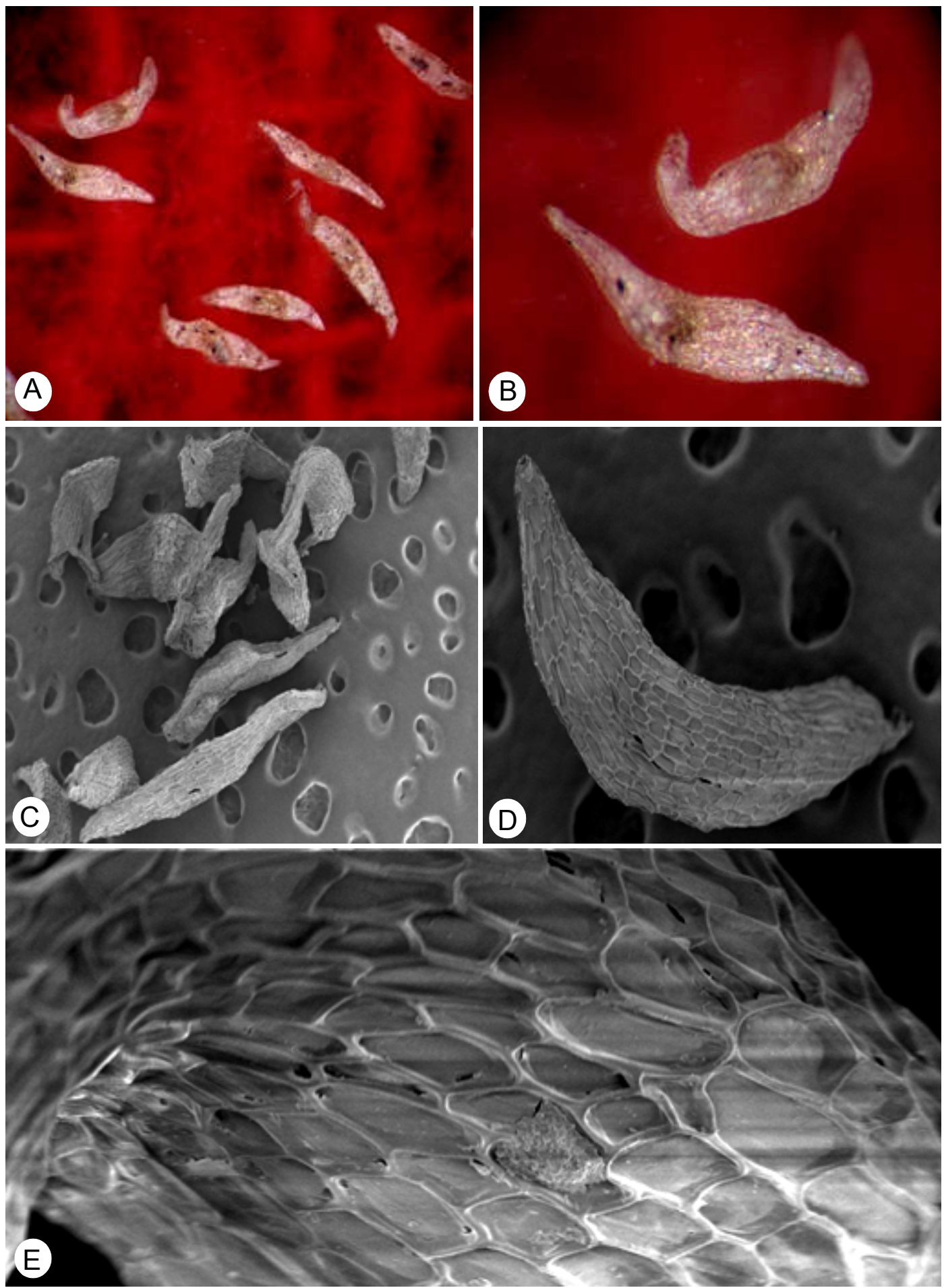

PLATE III. Seed morphometry of Dactylorhiza umbrosa : A \& B. Seeds and single seed in closer view under Stereo-zoom microscope; C - E. Seed shape, coat and testa cells under Scanning Electron Microscope 

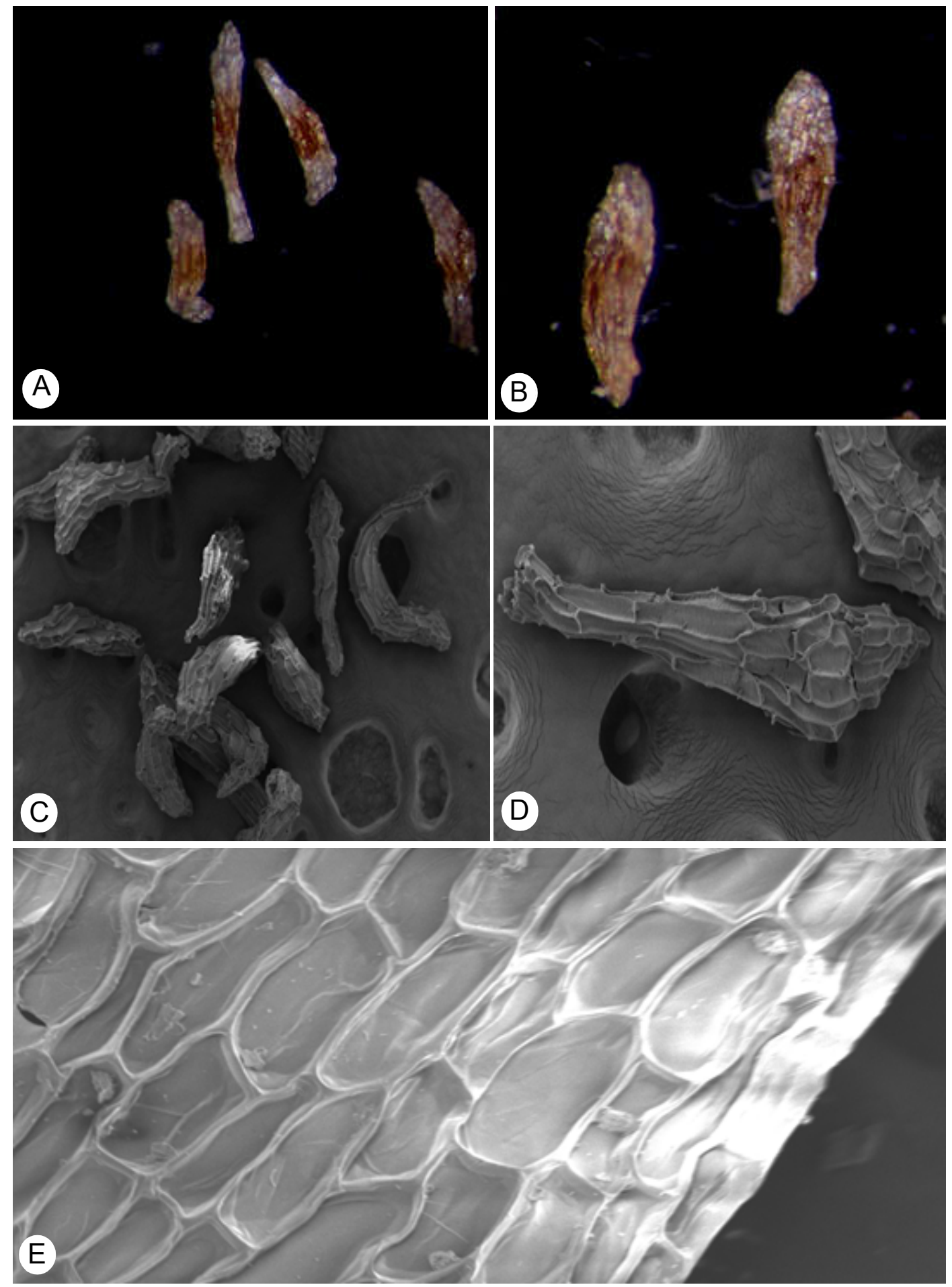

PLATE IV. Seed morphometry of Dactylorhiza viridis : A \& B. Seeds and single seed in closer view under Stereo-zoom microscope; C - E. Seed shape, coat and testa cells under Scanning Electron Microscope 
Table 2. Seed morphometry of four Dactylorbiza species of Kashmir Himalaya, India

\begin{tabular}{|c|c|c|c|c|c|c|}
\hline \multirow[b]{2}{*}{ Species } & \multicolumn{3}{|c|}{ Seeds } & \multicolumn{3}{|c|}{ Testa cells } \\
\hline & Shape & $\begin{array}{l}\text { Length } \\
\text { (mm) }\end{array}$ & $\begin{array}{l}\text { Width } \\
(\mathrm{mm})\end{array}$ & Shape & $\begin{array}{l}\text { Length } \\
\quad(\mu \mathrm{m})\end{array}$ & $\begin{array}{l}\text { Width } \\
(\mu \mathrm{m})\end{array}$ \\
\hline D. hatageria & Spathaulate & $0.36 \pm 0.05$ & $0.16 \pm 0.001$ & $\begin{array}{l}\text { Ovoid and } \\
\text { rectangular }\end{array}$ & $345 \pm 240$ & $230 \pm 170$ \\
\hline D. kafiriana & Crescent & $0.85 \pm 0.01$ & $0.10 \pm 0.003$ & Rectangular & $560 \pm 340$ & $90 \pm 65$ \\
\hline D. umbrosa & Elliptical & $0.67 \pm 0.02$ & $0.27 \pm 0.003$ & Pentagonal & $180 \pm 130$ & $30 \pm 25$ \\
\hline D. viridis & Spathaulate & $0.25 \pm 0.02$ & $0.17 \pm 0.004$ & $\begin{array}{l}\text { Ovoid and } \\
\text { rectangular }\end{array}$ & $320 \pm 290$ & $180 \pm 110$ \\
\hline
\end{tabular}

2014) and the shape, size and wall thickening pattern have great utility in taxonomic delimitation (Healey et al. 1980). The authors are of the opinion that the findings from the present study may be effectively used for taxonomic delimitation of the species in future revisionary studies of the genus Dactylorbiza.

\section{Acknowledgments}

Authors are highly thankful to the Head, Department of Botany, University of KashmirSrinagar, for providing necessary facilities to carry out this work. They also acknowledge the kind help of Mr. Tariq Ahmad of USIC, University of Kashmir in SEM studies. Authors are also highly thankful to Late. Prof. Suraj Prakash Vij and Prof. Promila Pathak of Department of Botany, Punjab University Chandigarh, India for their valuable suggestions and for providing relevant literature.

\section{LITERATURE CITED}

Akbulut, M. K. \& ${ }^{a}$ enel, G. 2016.The seeds micromorphology and morphometry of certain Dactylorbiza (Orchidaceae) species distributed in Turkey. RendicontiLincei 27(4): 679 - 686.

Akçin, T.A.; Ozdener, Y. \& Akçin, A. 2010 .Taxonomic value of seed characters in orchids from Turkey. Belgian Journal of Botany 142(1): 124 - 139.

Arditti, J. \& Ghani, A.K.A. 2000. Tansley Review No. 110. Numerical and physical properties of orchid seeds and their biological implications. The New Phytologist 145(3): $367-421$.

Arditti, J.; Michaud, J.D. \& Healey, P.L. 1980. Morphometry of orchid seeds. II. Native California and related species of Calypso, Cephalanthera, Corallorbiza and Epipactis. American Journal of Botany 67: $347-365$.

Arditti, J.; Michaud, J.D. \& Healey, P.L., 1979. Morphometry of Orchid Seeds. I. Paphiopedilumand native California and related species of Cypripedium. American Journal of Botany 66 (10): $1128-1137$.

Augustine, J.; Kumar, Y. \& Sharma, J. 2001.Orchids of India. II. Biodiversity and status of Bulbophyllum Thou. Daya, New Delhi.

Barthlott, W. \& Ziegler, B. 1981. Morphologie der Samenschalenalss ystematische Merkmalbeiorchideen. Ber. Dtsch. Bot. Ges. 94: 267 - 273. 
Chase, M.W. \& Pippen, J.S. 1988. Seed morphology in the Oncidiinae and related subtribes (Orchidaceae). Systematic Botany 13(2): 313 - 323.

Chemisquy, M.A.; Prevosti, F.J. \& Morrone, O. 2009. Seed morphology in the tribe Chloraeeae (Orchidaceae): combining traditional and geometric morphometrics. Botanical Journal of the Linnean Society 160(2): $171-183$.

Gamarra, R.; Galan, P.; Herrera, I. \& Ortunez, E. 2008. Seed micromorphology supports the splitting of Limnorchis from Platanthera (Orchidaceae). Nordic Journal of Botany 26(1 2): $61-65$.

Gamarra, R.; Ortunez, E.; Sanz, E.; Esparza, I. \& Galan, P. 2010. Seeds in subtribe Orchidinae (Orchidaceae): the best morphological tool to support molecular analyses. EUT Edizioni Universita di Trieste

Healey, P.L.; Michaud, J.D. and Arditti, J. 1980. Morphometry of orchid seeds. III Native California and related species of Goodyera, Piperia, Platanthera and Spiranthes. American Journal of Botany 67: 508 - 518.

Kaya, A.; Unal, M.; Ozgokce, F.; Dogan, B., \& Martin, E. 2011. Fruit and seed morphology of six species previously placed in Malcolmia (Brassicaceae) in Turkey and their taxonomic value. Turkish Journal of Botany 35(6): 653 - 662.

Rasmussen, H.N. 1995. Terrestrial orchids: from Seed to Mycotrophic Plant. Cambridge University Press, Cambridge, UK.

Swamy, K.K.; Kumar, H.K.; Ramakrishna, T.M. \& Ramaswamy, S.N. 2004. Studies on seed morphometry of epiphytic orchids from Western Ghats of Karnataka. Taiwania 49(2): $124-140$.

Swamy, M.K.; Mohanty, S.K. \& Anuradha, M. 2014.The effect of plant growth regulators and natural supplements on in vitro propagation of Pogostem oncablin Benth. Journal of Crop Science and Biotechnology 17(2): $71-78$.

Verma, J.; Thakur, K.; Sembi, J.K. \& Vij, S.P. 2012. Study on seed morphometry of seven threatened Himalayan orchids exhibiting varied life modes. Acta Botanica Gallica 159(4): $443-449$.

Verma, J.; Sharma, K.; Thakur, K.; Sembi, J.K. \& Vij, S.P. 2014. Study on seed morphometry of some threatened Western Himalayan orchids. Turkish Journal of Botany 38(2): 234 251.

Verma, J.; Thakur, K. \& Vij, S. P. 2013.On the occurrence of an interesting leafless orchid Neottia listeroides Lindl.In Himachal Pradesh, northwestern Himalaya, India. Journal of Threatened Taxa 5(11): 4601 - 4603.

Vij, S. P.; Kaur, P.; Kaur, S. \& Kaushal, P.S..1992. The orchid seeds: taxonomic, evolutionary and functional aspects. Journal of Orchid Society of India 6: $91-107$. 